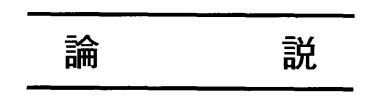

\title{
慢性副鼻腔炎鼻汁の成因と対策
}

\author{
間 島 雄一
}

\section{Pathogenesis of Nasal Mucus Hypersecretion in Chronic Sinusitis}

\author{
Yuichi Majima \\ (Mie University)
}

\begin{abstract}
Nasal mucus hypersecretion is a feature of chronic sinusitis (CS). Bacterial infection, which initiates neutrophil accumulation in the nose and sinuses is an initial cause of CS. The specific neutrophil products to stimulate mucus glycoprotein (MGP) secretion are neutrophil elastase, cathepsin $\mathrm{G}$ and platelet-activating factor. Eicoanoids are a group of lipids derived from arachidonic acid that is released from the cell membranes of inflammatory and epithelial cells, and also contribute to MGP production. Bacterial products, such as lipopolysaccharide and elastase from some bacteria, are potent secretagogues. Such products derived from inflammatory cells and bacterias are retained in sinuses for a long time because of obstruction of the sinus ostium and mucociliary dysfunction of the nose and sinuses. Submucosal gland cells are hyperplastic and hypertrophic but goblet cells are not, and the major source of MGP hypersecretion is submucosal gland cells rather than goblet cells. The role of neural innervation of submucosal glands on MGP overproduction has not yet to be elucidated.

The rheologic properties of nasal mucus from CS patients are much higher than the optimal viscoelasticity for mucociliary transport. Since MGP mainly determines the high viscosity and the high elasticity of nasal mucus, a control of MGP production could contribute to the normalization of abnormal viscoelasticity, and result in the improvement of mucociliary clearance. This is accomplished by removing the sinus retention that contains many secretagogues. Although current pharmacological approaches to airway mucus production are limited, glucocorticoid appears to be the most effective among the few useful drugs. The effect of 14-membered macrolide antibiotics on MGP production is still controversial. Some mucolytic agents change the conformations of MGP and lead to the reduction of viscoelasticity when they are administered topically or systemically. CS.

The mechanisms of nasal mucus hypersecretion are also discussed in relation to the etiology of
\end{abstract}

Key words : nasal mucus, hypersecretion, chronic sinusitis, mucus glycoprotein

はじめに

慢性副鼻腔炎は本邦に括いては䍜患患者数も減少傾向

にありまた軽症化の傾向にあるとされているが，なお

臨床上, 重要な鼻疾患である. またアレルギー性鼻炎な
ぞの増加は本邦の鼻疾患の欧米化を示唆しているが，米 国に扣ける慢性副鼻腔炎(以下，副鼻腔炎とする)の罹患 率は 3,100 万人以上1) であり, 副鼻腔炎が生活形態や衛 生思想などの欧米化によっても消失するものでないこと 
が予想できる.

副鼻腔炎の症状は, 鼻漏と鼻閉に代表される. ちなみ に副鼻腔炎の治療効果を評価するためにしばしば用いら れる自覚症状の判定項目2)では鼻漏, 鼻のかみやすさ, 後鼻漏, 後鼻漏のきれ, 鼻閉, 頭重感, 嗅覚障害の 7 項 目が挙げられているが, このらち鼻漏, 鼻のかみやすさ, 後鼻漏, 後鼻漏のきれ, 鼻閉と 7 項目中 5 項目に鼻漏す なわち鼻汁が関与している.このよらに副鼻腔炎の症状 発現に大さな影響を有する鼻汁はどのように産生され， いかに克服してゆけばよいのであろらか. 本論説ではこ の点につき，われわれの研究成果を中心に文献的考察も 含めて明らかにしたい。

\section{慢性副鼻腔炎の成因}

鼻汁の成因を論ずる前に副鼻腔炎の成因について述べ てみたい，何故なら副鼻腔炎の成因と鼻汁の産生とは密 接な関係にあるからである. 副鼻腔炎の成因には感染， 遺伝的素因そして特殊な疾患によるものとに分けること ができる3.ここのち感染によるところが最も一般的な 成因であろら。

図 1 はわれわれが提唱している副鼻腔炎の慢性化の要 因としての自己由来の炎症 “self-mediated inflamation” の概念である4).ここでは副鼻腔炎の契機としてまず細
菌感染が存在することを示している．細菌感染によって 局所火炎症細胞が浸潤すると, これらの炎症細胞から遊 離する種々のメディエーターや蛋白分解酵素, それに細 菌由来物質が局所に炎症を生じ, この結果副鼻腔自然孔 や ostiomeatal complex の狭窄または閉塞を生じる。こ のため副鼻腔が換気障害に陥り, 副鼻腔内の酸素分圧の 低下, 炭酸ガス分圧の上昇により副鼻腔は酸性に傾き, この状態は副鼻腔での細菌の増殖を促進することになる。 また自然孔の閉鎖は粘液線毛機能による副鼻腔からの貯 留液の排泄を阻害し, 副鼻腔に貯留液が長期にわたり停 滞することとなる(図 1 の $\mathrm{R}-1$ ). 一方, 細菌感染によ り局所に遊走した炎症細胞由来の物質や細菌由来物質は 上皮の分泌細胞に働いて鼻腔や副鼻腔の粘液(鼻汁)産生 を六進する ${ }^{5)}$. 粘液量の増加と粘液の物理学的性質異常 は鼻・副鼻腔の粘液線毛機能障害の原因となり, 鼻腔や 副鼻腔からの粘液の排泄が障害される6)（図 1 の-2）. さらに細菌感染や炎症細胞由来物質は副鼻腔に未ける組 織障害を生じ, 線毛細胞の減少と線毛の脱落》は粘液線 毛機能障害を生じる(図 1 の $\mathrm{R}-3$ )。このようにして副 鼻腔に停滞した貯留液中には炎症細胞由来のメディェー ターや蛋白分解酵素, 細菌由来物質, 免疫複合体などの 種々の物質が含まれて和り，これらが長期にわたって副 鼻腔に留ることにより,さらに副鼻腔に怙ける組織障害

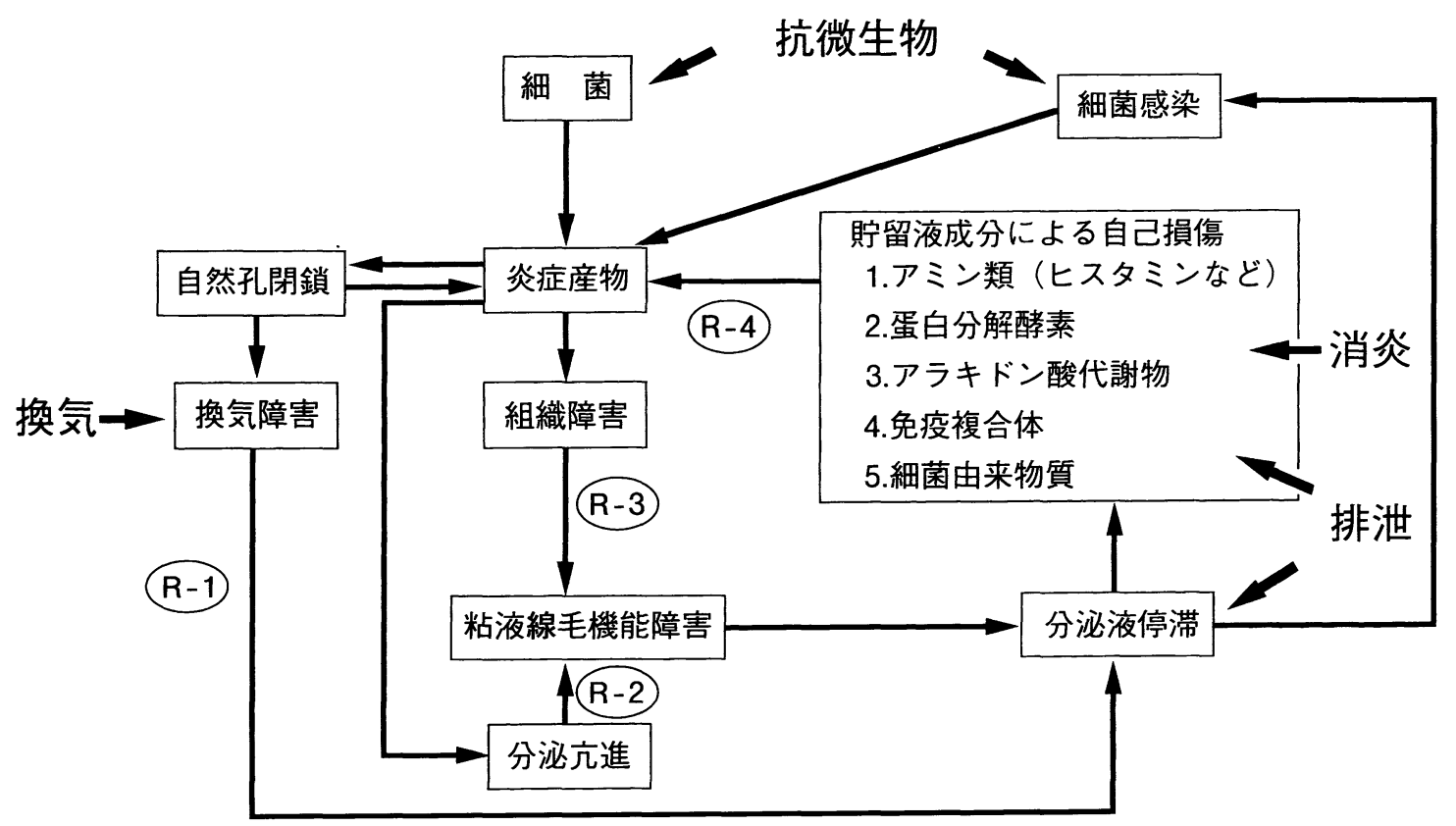

図 1 慢性副鼻腔炎の成因とその対策 
や粘液産生が亢進して炎症が遷延化するという悪循環を 生じることになる（図 1 のR-4）。ここで明らかなよう に副鼻腔炎の成因と粘液産生は重要な関係にあるわけで, これについては後で詳細に述べることとする。

副鼻腔炎の成因としての遺伝的要素については以前よ りその可能性が指摘されてきている. 高度の副鼻腔炎を 有する日本人で HLA B54 抗原の保有率は $29.3 \%$ であっ た ${ }^{8)}$. HLA B54 抗原はアジア人に特有な抗原で日本人

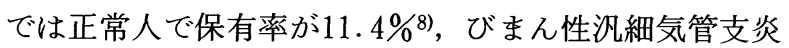
(DPB) で63.2\% ${ }^{9)}$, 副鼻腔気管支症候群では50\%10) とさ れている．慢性副鼻腔炎はDPB ほどではないにしても その原因の一つとして遺伝的素因が関与しているものと 考兄られる. 副鼻腔炎, DPB ともに気道粘液 (鼻汁や喀 痰)の過分泌が生じるわけで, このような遺厷的要素が 関与する気道疾患に拈ける粘液産生の機序はいまだ明確 にされていない。

特殊な疾患によるものでは原発性線毛運動不全症が本 邦では代表的である. 本疾患では線毛運動不全があるた めに正常の粘液線毛機能が得られず，上下気道の慢性炎 症性疾患をきたすわけであるが，この現象からみても図 1 の R-3 亿示されたごとく粘液線毛機能障害が副鼻腔 炎の成因に果たす影響は大きいものと想像されよう。な 抢，特殊な疾患ではないが鼻腔形態の異常11)，特に ostiomeatal complex の形態12) は同部位や自然孔閉鎖の原 因となりやすく図 1 のR-1 の経路を通じて副鼻腔炎の 成因に関与しているものと考兄られる.

\section{慢性副鼻腔炎鼻汁の由来}

鼻汁は涙, 呼気から凝結した水, 血液成分や組織液の 移行, 水やイオンの移行, 粘液なぞの混合物である13). しかし，なかでも中心的存在は溶媒としての水と溶質と しての粘液糖蛋白 (mucus glycoprotein, 以下 MGP) で ある. 水は主として粘膜上皮や分泌細胞を介して漿膜側 から管腔側へ移行することにより生じるわけであるが， 逆に管腔側から漿膜側への水の吸収も存在するわけで, このような水の移動は細胞内のイオン輸送によることが 知られている.ここでは紙数の関係もあり水の移動につ いては言及せず，もら一つの中心的な存在である MGP に焦点を絞って述べることとする.

MGP は分泌細胞により分泌される．分泌細胞には杯 細胞と腺細胞があるのは周知のごとくであるが，副鼻腔 炎では主としてどちらの分泌細胞から産生されるのであ
ろらか. 副鼻腔炎の上顩洞粘膜では正常のそれに比べ腺 細胞数が有意に高値を示したが，杯細胞数には両者の間 飞差を認めなかった ${ }^{14)}$. Tos ら ${ }^{15)}$ は副鼻腔炎上䫈洞粘膜 に扣ける腺細胞数の増加と杯細胞数の減少を報告してい る.これらの結果より副鼻腔炎では MGP の産生は主と して腺細胞より産生されているといえよう，慢性副鼻腔 炎の鼻粘膜でも上頸洞粘膜と同様に腺細胞数の増加が認

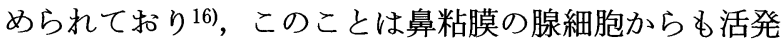
なMGP の産生がなされていることがらかがえる。い かえれば副鼻腔炎では副鼻腔の久ならず鼻腔も鼻汁の過 剩産生に大きく関与しているといえよう。

\section{慢性副鼻腔炎における粘液糖蛋白の過分泌}

1. 神経支配による腺分泌の充進

杯細胞には神経支配はないが，腺にはコリン作動性神 経, アドレナリン作動性神経, 非アドレナリン非コリン (NANC) 作動性神経が分布している．コリン作動性神経 に対する腺の受容体は現在のところ $\mathrm{M} 1 ， \mathrm{M} 2, \mathrm{M} 3$ が確 認されており，また受容体は腺の漿液細胞と粘液細胞の 両方に同程度存在することから，本神経刺激により漿液， 粘液両細胞からの MGP の分泌が生じるものと考兄られ ている17)。腺に和けるアドレナリン受容体は $\alpha_{1}, \alpha_{2}, \beta_{1}$, $\beta_{2}$ の 4 種類が報告されている， $\alpha_{1}$ 受容体は漿液細胞に 多く, $\beta$ 受容体は粘液細胞に多い18). したがって $\alpha$ 受容 体刺激により漿液細胞から， $\beta$ 受容体刺激により粘液細 胞からの分泌が充進するわけで，前者の刺激により分泌 物の粘稠度は低下し, 後者の刺激によりそれは上昇す $る^{19)}$. NANC 作動性神経の神経伝達物質として二ュー ロペプタイドがあり，このうち，SP, VIP は腺からの 粘液分泌を六進することが知られている.

腺からの分泌は腺からの MGP の産生の妄進によるも のと, 筋上皮細胞の収縮によって腺自体が収縮すること により腺で産生された MGP が一気に放出されることに よるものとの 2 通りの分泌機構が存在する. 腺の収縮に 主として関与するのはコリン作動性神経刺激であり, 数 分以内の短時間刺激によって生じる. 一方, MGP の産 生にはコリン作動性神経, アドレナリン作動性神経, NANC 作動性神経とも15分以上の刺激が必要である20). 副鼻腔炎に护ける MGP の過分泌にこれらの神経支配が ぞの程度関与しているかは明らかにされていないが，抗 コリン剤の鼻内投与が副鼻腔炎鼻汁の過分泌を抑制する ことができないことから，副鼻腔炎では神経支配による 
腺分泌の亢進よりも炎症産物による腺分泌の克進が主体 をなしていると想像される.

2. 炎症産物による分泌の六進

表 1 5211 34) に分泌細胞からの MGP 産生促進物質を 過去の報告を参考にまとめた。これらの報告の多くが in vivo の動物実験か in vitro の研究結果によるもので あり，ヒトの鼻・副鼻空にすべてが適応されるものとは いいきれないが，大いに参考となる．炎症の場に出現す る炎症細胞からはアラキドン酸代謝物をはじめとして種 種の MGP 産生促進物質が遊離されていることがわかる. また, 補体の一部, サイトカインや細胞増殖因子, それ に細菌由来物質もMGP の産生を促進することが理解さ れよう。それでは副鼻腔炎においてこのような炎症産物 がいかに関与しているかを考劣てみよう。

副鼻腔炎に拈ける分泌充進のメカニズムを考兄るには 図 1 亿示した副鼻腔炎の発症機序に従うと理解しやすい. 細菌感染が発症の契機となって局所に炎症細胞が浸潤す るが，炎症細胞の主役をなすのは急性においても慢性に おいても好中球である. 副鼻腔炎患者の鼻汁中好中球は 全炎症細胞の $96 \%$ 以上占め, その単位鼻汁量当たりの 数は正常鼻汁に比べ粘性鼻汁で約 20 倍, 粘膿性鼻汁では 実に100倍以上を示す35). 好中球からはエラスターゼ,
表 1 粘液糖蛋白産生促進物質

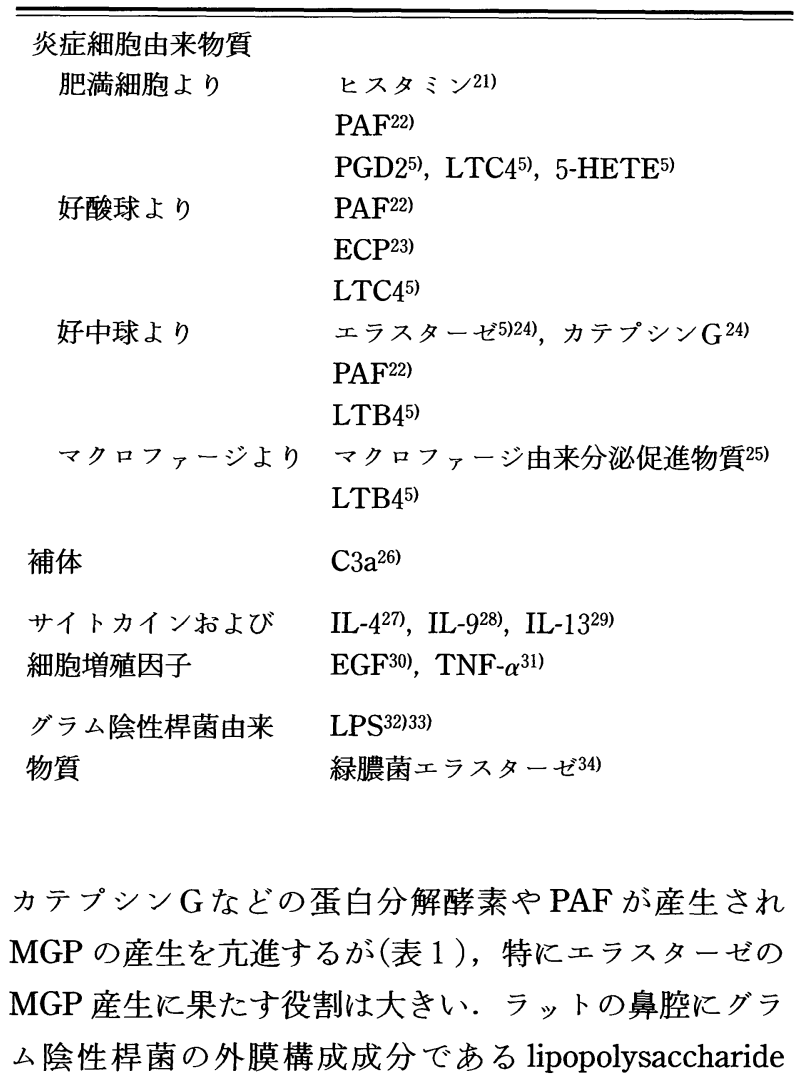

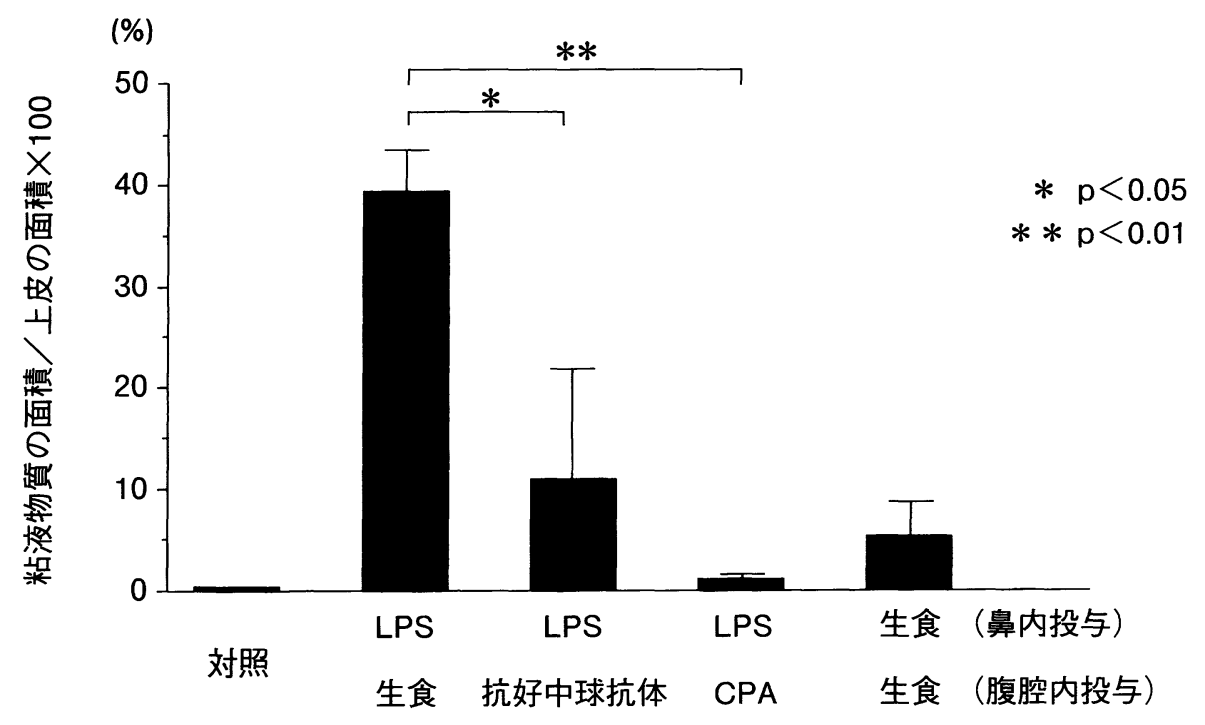

図 2 粘液糖蛋白産生に及ぼす好中球の役割 (Simizu T, et al : Am J Respir Crit Care Med $153: 1996^{32)}$ より改変)

ラット鼻腔に LPS を投与すると, 鼻粘膜杯細胞の MGP 産生の著名な亢進を認め る. 一方, 腹腔内に抗ラット好中球抗体を投与するとLPSによる杯細胞からの MGP 産生は抑制される.この現象は腹腔内にサイクロフォスファマイド (CPA)を 投与して好中球減少を若起した場合も同様であった. 
(LPS) を投与した場合に杯細胞からの MGP 産生がえ進 するが，このラットの腹腔に抗ラット好中球抗体を投与 すると MGP 産生が抑制される(図 2 ) 32).すなわち LPS によって杯細胞に括ける MGP の産生は元進するが，こ の六進は抗好中球抗体で好中球を枯渴させることにより 抑制される，な拉，生体では好中球からの蛋白分解酵素 に対するインヒビターが存在し，これが生体を防御して いるが蛋白分解酵素の量がインヒビターの量を上回ると， 蛋白分解酵素が生体にとって負の働きをすることとなる。 副鼻腔炎の存在する局所では蛋白分解酵素がインヒビ ターを凌駕しているものと考兄られる.

副鼻腔炎鼻汁中に存在する好中球を中心とした炎症細 胞の膜構成成分から由来するアラキドン酸代謝物は副鼻 腔炎鼻汁中に高濃度に存在することから ${ }^{36)}$, アラキドン 酸代謝物が MGP 産生に関与している可能性は高い．末 た炎症細胞からのPAF も同様の働きをしているものと 考兄られる。ささて，LPSがMGP の産生を充進させる ことはすでに述べたが，このメカニズムは遺伝子レベル で明らかにされつつある. LPS は分泌細胞の転写調節 因子の一つである NF- $\kappa \mathrm{B}$ を活性化することで，ある種 のムチン遺伝子の転写を促進する ${ }^{33}$. ムチン遺伝子は粘 液糖蛋白の蛋白部分をコードする遺伝子であり, 現在 MUC1 から MUC8 まで 9 種類のムチン遺伝子が同定さ れている. 表 1 に示した MGP 産生促進物質は何らかの
機序でムチン遺伝子の発現を促進して MGP の産生をえ 進しているものと考兄られ, どの物質がどのような機序 で，どのムチン遺伝子の発現を増強するかについては今 後の検討課題であろう. 副鼻腔自然孔の狭窄や閉鎖に よって，好中球由来の蛋白分解酵素，アラキドン酸代謝 物，それにLPS などの細菌由来物質が長期に副鼻腔に 停滞することになり，これらがさらに分泌細胞からの MGP の産生をえ進させることとなる.

\section{慢性副鼻腔炎鼻汁の物性}

鼻漏や喀痰, 中耳貯留液, 唾液など人体のあらゆる液 性成分の物理的性質は弾性率 $\left(\mathrm{G}^{\prime}\right)$ と粘性率 $\left(\eta^{\prime}\right)$ で表現さ れる.すなわち鼻漏の物性の基本は弾性と粘性というこ とになる. 副鼻腔炎鼻汁は正常鼻汁に比べはるかに高い $\mathrm{G}^{\prime}$ と只值を有している6).

さて，このような $\mathrm{G}^{\prime} と \eta^{\prime}$ の測定結果が臨床的にどの ような意味を持つかを考兄てみたい，図 3 は粘液が線毛 によって運搬される速さ，すなわち粘液線毛輸送速度と 気道液の $\mathrm{G}^{\prime}$ との関係を示したものである．粘液が線毛 により最も速く運搬される $\mathrm{G}^{\prime}$ 值は $20 \mathrm{dyne} / \mathrm{cm}^{2}$ であり, この值よりも $\mathrm{G}^{\prime}$ 值が高くなればなるほど，また低くな ればなるほど，粘液線毛輸送速度は低下した．同様の関 係は粘液線毛輸送速度と $\eta^{\prime}$ との間にも存在し，最も効 果的な輸送速度を得られる $\eta^{\prime}$ 值は 2.0 poise であった

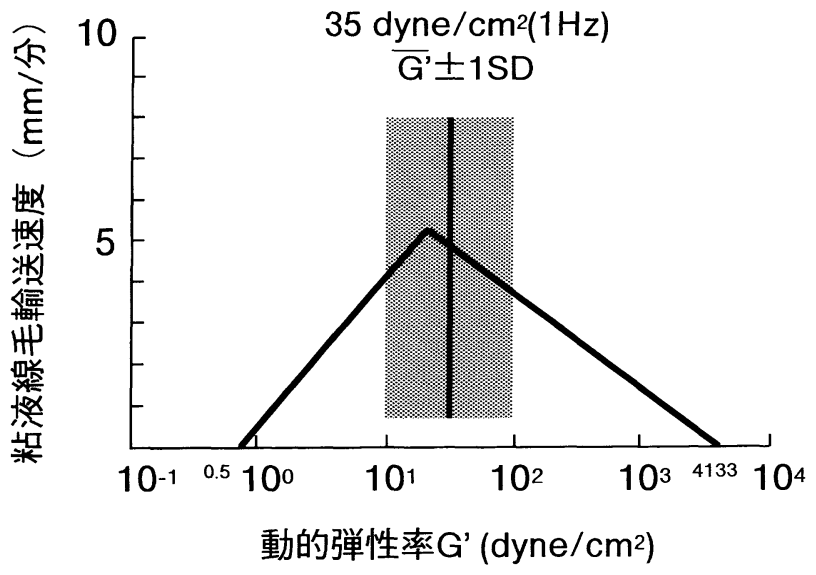

a

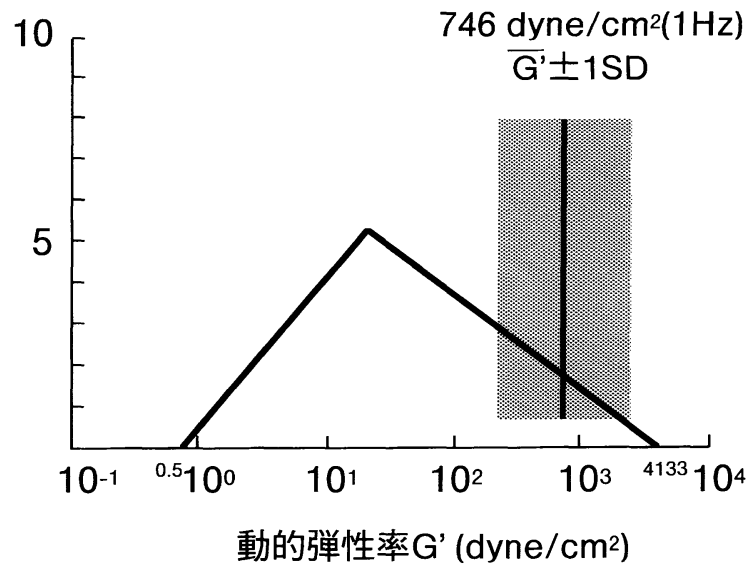

b

図 3 弾性率と粘液線毛機能との関係 (Majima Y, et al : Rhinology up-to-date, Industrial Grafica Romana 19946)より引用) 弾性率 $\left(\mathrm{G}^{\prime}\right)$ が $20 \mathrm{dyne} / \mathrm{cm}^{2}$ で最も速い粘液線毛輸送速度が得られ, $\mathrm{G}^{\prime}$ が $20 \mathrm{dyne} / \mathrm{cm}^{2}$ 以上では $\mathrm{G}^{\prime}$ と輸送速度との間 には負の相関が, 20 dyne $/ \mathrm{cm}^{2}$ 以下では正の相関が認められる.

a : 正常鼻汁の $G^{\prime}$ を示す. 正常鼻汁は効果的な粘液線毛輸送速度が得られる $\mathrm{G}^{\prime}$ を有している.

$\mathrm{b}$ ：慢性副鼻腔炎鼻汁の $\mathrm{G}^{\prime}$ を示す。副鼻腔炎鼻汁は $\mathrm{G}^{\prime}$ 值が高く, 効果的な輸送速度を得ることができない. 
図 3-a K正常鼻汁の $\mathrm{G}^{\prime}$ 值の平均とその分布を示して いるが，正常鼻汁は効果的な粘液線毛輸送速度を得る値 を有しているといえる.同様のことが正常鼻汁の $\eta^{\prime}$ 值 について確認された。一方, 副鼻腔炎鼻汁の $G^{\prime}, \eta^{\prime}$ 値 は正常鼻汁に比し，はるかに高値を示し，線毛により効 果的に運搬され難いことがわかる(図 3-b $)^{6}$. 副鼻腔 炎患者の鼻腔の粘液線毛輸送機能は低下していることが 知られて扣り37)，この低下の原因の一つに本患者鼻汁の 高い $G^{\prime}, \eta^{\prime}$ が関与しているものと考学られる。また， 副鼻腔炎鼻汁の $\mathrm{G}^{\prime}, \eta^{\prime}$ は高値を示すため軟口蓋の挙上 により上咽頭で切断されにくく, 鼻汁が鼻腔から咽頭に 向かって連なることにより後鼻漏を自覚する原因とな $ろ^{38)}$.

副鼻腔炎鼻汁の高い $\mathrm{G}^{\prime}, \eta^{\prime}$ は鼻汁のどのよらな組成 によるものであろらか，これを知るために鼻汁の主な成

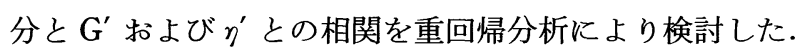
その結果, 鼻汁中のフコース濃度が $G^{\prime}, \eta^{\prime}$ の最も重要 な決定因子であり，次いで重要な決定因子が鼻汁中の IgG 濃度であった．そしてフコース濃度と IgG 濃度を 合わせると $\mathrm{G}^{\prime}$ 和よびグ 值の $73 \%$ 決定されることが明 らかとなった ${ }^{39)}$. ちなみに慢性副鼻腔炎鼻汁の $\mathrm{G}^{\prime}, \eta^{\prime}$ と 鼻汁中のフコース濃度との単相関を図 4 亿示すが, 両者 の間にはきわめて高い正相関が存在することがわかる39). フコースはMGP のマーカーであることが知られている ことから, 副鼻腔炎の高い弾性率, 粘性率の決定に MGP が主役をなしていることが明らかであろう.

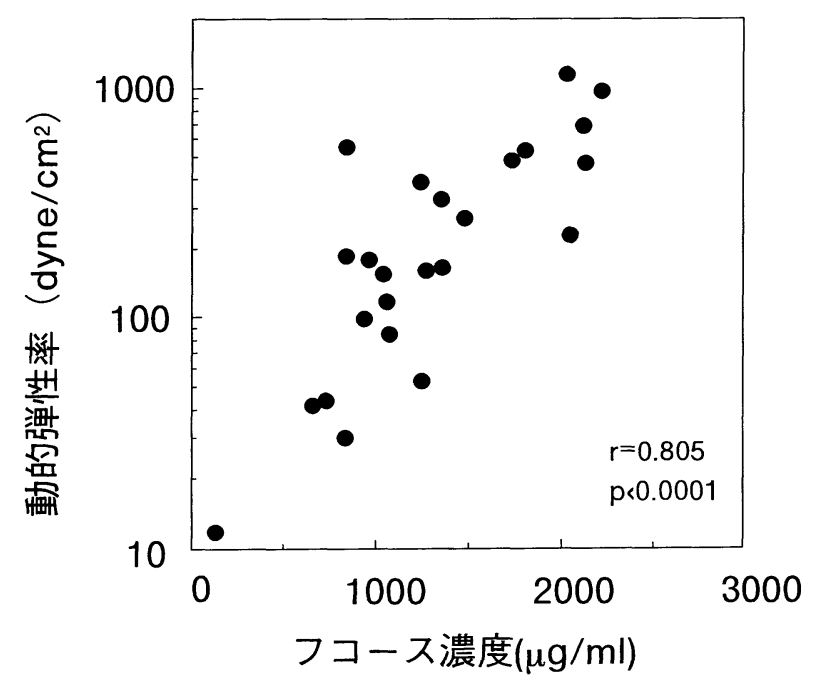

\section{慢性副鼻腔炎鼻汁への対策}

1. 慢性副鼻腔炎の成因の排除

副鼻腔炎の治療によって副鼻腔炎を遷延化させている 図 1 の悪循環が断ち切られると鼻汁量も減少してゆくこ とは臨床上経験されるところである. 上須洞洗浄施行前 の鼻汁と洗浄を繰り返して上靧洞病変が改善した鼻汁と ではその $\mathrm{G}^{\prime}, \eta^{\prime}$ ともに施行前に比し施行後に低下がみ られることから ${ }^{40)}$, 副鼻腔病変の改善によって分泌細胞 からの MGP の過剩産生も改善していることが予想され る.したがって副鼻腔の換気を改善し, 種々の MGP 産 生促進物質を含む副鼻腔貯留液を排除させることがでさ る治療法が現時点においては鼻汁量を減少させる最も有 用な手段である.これには鼻内副鼻腔手術を筆頭として 上顎洞洗浄療法や YAMIK 療法がある.

\section{2. 薬物療法}

（1）粘液糖蛋白産生の抑制

ステロイドはin vivo, in vitro に拈いて MGP の産生 を抑制することが知られている200. この作用機序として はステロイドが分泌細胞の $\mathrm{I} \kappa \mathrm{B} \alpha$ の発現を誘導して NF$\kappa \mathrm{B}$ の活性化を抑制し, ムチン遺伝子の転写の促進を抑 制する可能性 41$)$ とアラキドン酸代謝に沶いてアラキド ン酸代謝物の産生を抑制するリポコルチンの産生を充進 させる可能性が報告されている42). このよらな点からス テロイドの局所投与は副鼻腔炎鼻汁の産生抑制に有効と 考觉られるが，その臨床効果についてはさらなる検討の 余地があろら。

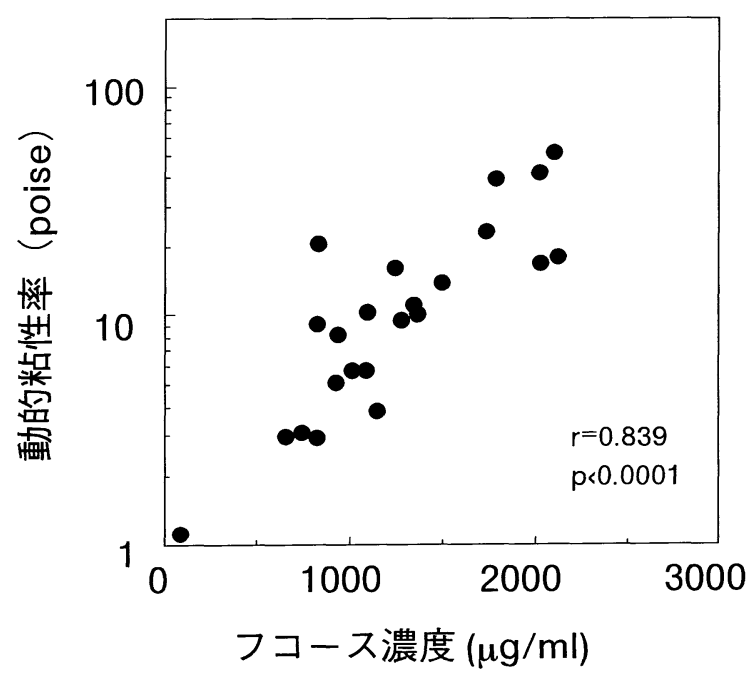

図 4 弾性率・粘性率とフコース濃度との相関 (Majima Y, et al : Am J Respir Crit Care Med $160: 1999^{39)}$ より改変) 
14員環マクロライド抗生物質は症例にもよるが，副鼻 腔炎鼻汁の減少に有効である.このメカニズムについて は不明な点が多い. 現在報告されている主な可能性はス テロイドと同様に NF- $\kappa \mathrm{B}$ の活性化を抑制する, 転写促 進因子の AP-1 の発現を抑制して炎症性サイトカインの 産生を抑制する，好中球からの炎症性メディェーターの 遊離を抑制する, 漿膜側より管腔側への水の移動を抑制 するなどである. マクロライドの鼻汁抑制に対する効果 発現の機序の解明については今後の研究成果を期待した い.

（2）鼻汁の物性の改善

MGP は一つの分子でも大きな分子であるがこの分子 が S-S 結合やその他もろもろの結合により互いに結び つき, 複雑な網目構造を有した巨大な糖蛋白分子を形成 する.すなわち MGP の濃度のみならず糖蛋白の巨大な 分子や網状構造が弾性率, 粘性率に関与しているわけで ある. 副鼻腔炎に拉ける高い弾性率, 粘性率に MGP が 主として関与していることから，MGP の状態を変化さ せることにより, 副鼻腔炎鼻汁の物性を改善することが でさる．このよらな目的で用いられるのが従来から使用 されてきたいわゆる“去痰薬”である.

副鼻腔炎鼻汁に臨床的に使用される濃度の去痰薬を直
接投与した場合の効果を図 5 に示した.チオール製剤は MGP の S-S 結合を開裂する.チオール製剤であるアセ チルシステイン(ムュフィリン衴は最も効果的に $\mathrm{G}^{\prime}, \eta^{\prime}$ を低下させた。また界面活性剤と炭酸水素ナトリウムを 主成分とするアレベール®も有効であった。さらに $2 \%$ 炭酸水素ナトリウム液も $G^{\prime}$ の低下には有用であった ${ }^{43)}$. 鼻粘膜の表面は鼻汁の層に覆われていてネブライザーで 投与した薬液は容易に鼻粘膜に到達しない。したがって 去痰薬を本来投与すべき薬物とともにネブライザーで投 与することは, 去痰薬が鼻汁の MGP の網状構造をルー ズにして目的とする薬物を鼻粘膜に到達させるためにも 有用である.

チオール製剤の一つであるL-システインェチル塩酸 塩(チスタ二ン®)の 4 週間経口投与は慢性副鼻腔炎鼻汁 の $\mathrm{G}^{\prime}, \eta^{\prime}$ を有意に低下させた ${ }^{44)}$. また, 蛋白分解酵素で あるセラチオペプチダーゼ(ダーゼン®)の 4 週間投与も 副鼻腔炎鼻汁の $\eta^{\prime}$ を低下させた44)。この低下は経口投 与された蛋白分解酵素が MGP の糖鎖に覆われていない 部分のコア蛋白に作用して, MGP の分子を切断したか らであろらと想像されている. これらの薬物の経口投与 による $\mathrm{G}^{\prime}, \eta^{\prime}$ の低下は鼻汁に直接投与した場合に比べ, はるかに軽度であるが, 局所投与の場合とは違い薬物服

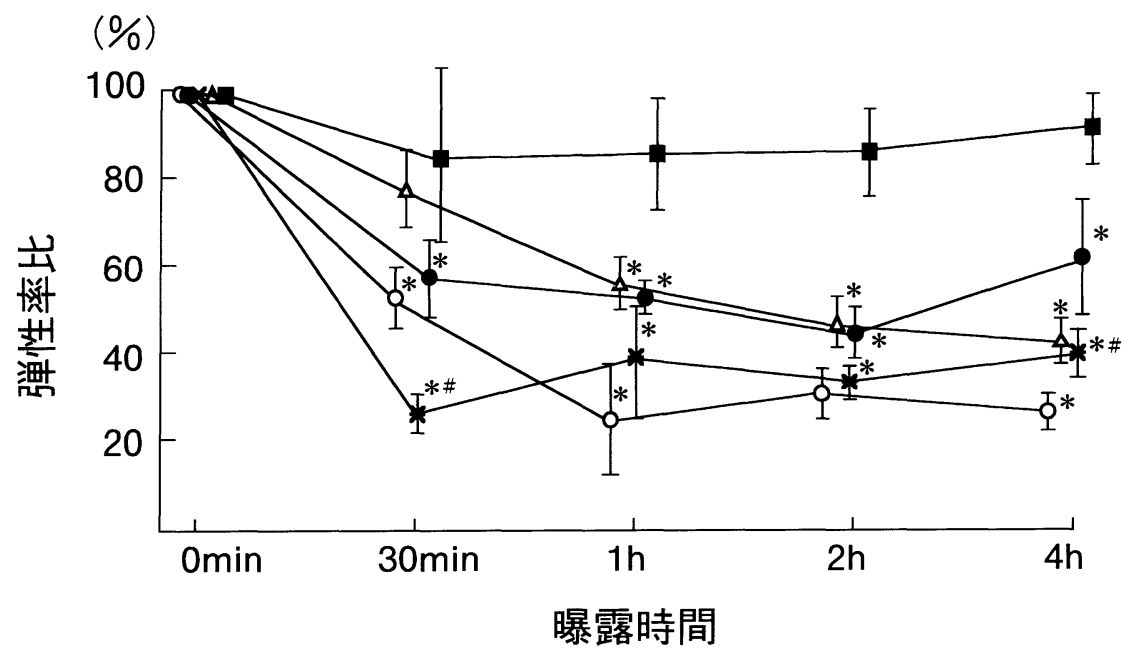

$$
\begin{aligned}
& \text { 匹: 水, } \Delta: 5000 \text { D Dase, ・: } 2 \% \text { 炭酸水素ナトリウム, } \\
& \text { ○: 10\%アセチルシステイン, } *: \text { アレベール }{ }^{\circledR}
\end{aligned}
$$

図 5 慢性副鼻腔炎鼻汁に及ぼす薬物の効果 (Rhee CS, et al : Arch Otolaryngol Head Neck Surg $125: 1999^{43)}$ より改変)

薬物投与前の弾性率を100として, 薬物投与後の弾性率を\%表示した. 
用中は効果が持続する長所を有している。なお，セラチ オペプチダーゼと14員環マクロライドの併用投与は気道 液へのマクロライドの移行を兄進させたといら報告もあ り ${ }^{45)}$, 去痰薬に対して科学的な視点からも5一度見直す 時期がきていると考えられる.

（3）薬物療法に括ける近未来の展望

14員環マクロライド抗生物質の長期投与は耐性菌の出 現の可能性もあり，抗菌活性を有しないが，鼻汁量を減 少させらる14員環マクロライドの誘導体の開発が望まれ る.また，好中球エラスターゼが MGP の産生に重要な 役割を果たしていることはすでに述べたが，このエラス ターゼに対する好中球エラスターゼ阻害剤が開発されて きている. 現在は下気道の慢性閉塞性疾患を対象疾患と しているが，好中球がその成因に大きな役割を果たして いる副鼻腔炎に対しネブライザーなどによる局所投与る 効果が期待されよう.

\section{おわりに \\ 副鼻腔炎の成因はすなわち鼻汁の過分泌の原因である ことを示した．多くの例で副鼻腔炎の成因を除去するこ とにより鼻汁の過分泌を制御することができる。一方, 副鼻腔炎の成因を除去できない例や除去できても鼻汁の 制御がでさない例も存在する。このような例では薬物療 法に期待せねばならないが，現時点での薬物療法ははな はだ心許ない状態とい党る。この点を解決するために臨 床と基礎両分野の本疾患に対する今後のさらなる精進に 期待したい。}

\section{参考文献}

1) Druce HM : Introduction; scope and epidemiology. Sinusitis (ed by Druce HM). pp 275 278, Marcel Dekker, New York, 1994.

2 ）間島雄一, 坂倉康夫 : 慢性副鼻腔炎に対する治療効果の他 覚的評価浪つい. 日鼻誌 $31: 294 \sim 302,1993$.

3 ) 間島雄一：慢性副鼻腔炎と遗伝. JOHNS $8: 1309 \sim 1311$, 1992.

4) Sakakura Y, Majima Y, Harada T, et al : Nasal mucociliary transport of chronic sinusitis in children. Arch Otolaryngol Head Neck Surg 118 : 1234 1237, 1992.

5 ) Lundgren JD and Shelhamer JH : Pathogenesis of airway mucus hypersecretion. J Allergy Clin Immunol $85: 399$ $\sim 417,1990$.

6) Majima $Y$ and Sakakura $Y$ : Rheological aspects of mucociliary clearance. Rhinology Up-to-date (ed by Pas- sali D). pp 127 137, Industrial Grafica Romana, Rome, 1994.

7) Guo Y, Majima Y, Hattori M, et al : Effects of functional endoscopic sinus surgery on maxillary sinus mucosa. Arch Otolaryngol Head Neck Surg 123: 1097 1100, 1997.

8 ) Takeuchi K, Majima Y, Shimizu T, et al : Analysis of HLA antigens in Japanese patients with chronic sinusitis. Laryngoscope 109 : 275 278, 1999.

9 ) Sugiyama Y, Kudoh S, Maeda H, et al : Analysis of HLA antigens in patients with diffuse panbronchiolitis. Am Rev Respir Dis 141 : 1459 1462, 1990.

10) Suzaki $H$, Ichimura $K$, Kudoh $S$, et al : Clinical observation in sinobronchial syndrome from a viewpoint of otorhinolaryngology. J Jpn Bronchoesophagol Soc 38 : 181 186, 1987.

11）堤 昌己：鼻腔形態と副鼻腔炎. 耳展 $19: 633 \sim 650,1976$.

12) Kennedy DW, Zinreich SJ, Shaalan H, et al : Endoscopic middle meatal antrostomy ; theory, technique, and patency. Laryngoscope 97 Suppl $43: 1 \sim 9,1987$.

13）坂倉康夫 : 気道液の由来. 上気道液の生理と病態. $11 \sim 12$ 頁, 協和企画通信, 東京, 1989 .

14）間島雄一, 堀みどり, 增田佐和子, 他：鼻・副鼻腔疾患の 鼻计過多に拈恀子分泌細胞之炎症細胞の役割。日鼻誌 32 : 304 309, 1994.

15) Tos $M$ and Mogensen $C$ : Mucus production in chronic maxillary sinusitis; a quantitative histopathological study. Acta Otolaryngol (Stockh) $97: 151 \sim 159,1984$.

16) Majima $Y$, Masuda $S$ and Sakakura $Y$ : Quantitative study of nasal secretory cells in normal subjects and patients with chronic sinusitis. Laryngoscope $107: 1515 \sim 1518$, 1997.

17) Basbaum $\mathrm{CB}$, Grillo MA and Widdicombe JH : Muscarinic receptors ; evidence for nonuniform distribution in tracheal smooth muscle and exocrine glands. J Neurosci 4 : 508 520, 1984.

18) Barnes PJ and Basbaum CB : Mapping of adrenergic receptors in the trachea by autoradiography. Exp Lung Res $5:$ : 183 192, 1983.

19) Leikauf GD, Ueki IF and Nadel JA : Autonomic regulation of viscoelasticity of cat tracheal gland secretions. J Appl Physiol $56: 426 \sim 430,1984$.

20) Shimura $S$ and Takishima $T$ : Airway submucosal gland secretion. Airway Secretion (ed by Takishima $\mathrm{T}$ and Shimura S). pp 325 398, Marcel Dekker, New York, 1994.

21) Tamaoki J, Nakata J, Takeyama K, et al : Histamine $\mathrm{H} 2$ receptor-mediated airway goblet cell secretion and its 
modulation by histamine degrading enzymes. J Allergy Clin Immunol $99: 233 \sim 238,1997$.

22) Rieves RD, Goff J, Wu T, et al : Airway epithelial cell mucin release ; immunologic quantitation and response to platelet-activating factor. Am J Respir Cell Mol Biol 6 : 158 167, 1992.

23) Lundgren J, Davey RT, Lundgren B, et al : Eosinophil cationic protein stimulates and major basic protein inhibits airway mucus secretion. J Allergy Clin Immunol 87 : $689 \sim 698,1991$.

24) Sommerhoff CP, Nadel JA, Basbaum CB, et al : Neutrophil elastase and cathepsin $\mathrm{G}$ stimulate secretion from cultured bovine airway gland serous cells. J Clin Invest $85: 682 \sim 689,1990$.

25) Sperber K, Chanez P, Bousquet J, et al : Detection of novel macrophage-derived mucus secretagogue (MMS-68) in bronchoalveolar lavage fluid of patients with asthma. J Allergy Clin Immunol $95:$ :868 876, 1995.

26) Marom $Z$, Shelhamer J, Berger M, et al : Anaphylatoxin $C$ 3a enhances mucous glycoprotein release from human airways in vitro. J Exp Med $161: 657 \sim 668,1985$.

27) Dabbagh K, Takeyama K, Lee HM, et al : IL-4 induces mucin gene expression and goblet cell metaplasia in vitro and in vivo. J Immunol $15: 6233 \sim 6237,1999$.

28) Louahed J, Toda M, Jen J, et al : Interleukin-9 upregulates mucus expression in the airways. Am J Respir Cell Mol Biol $22: 649 \sim 656,2000$.

29) Zuh Z, Homer RJ, Wang Z, et al : Pulmonary expression of interleukin-13 causes inflammation, mucus hypersecretion, subepithelial fibrosis, physiologic abnormalities, and eotaxin production. J Clin Invest $103: 779 \sim 788,1999$.

30) Guzman K, Randell SH and Nettesheim P : Epidermal growth factor regulates expression of the mucusphenotype of rat tracheal epithelial cells. Biochem Biophys Res Commun $217:$ 412 418, 1995.

31) Levine SJ, Larivee $P$, Logun $C$, et al : Tumor necrois factor- $\alpha$ induces mucin hypersecretion and MUC2 gene expression by human airway epithelial cells. Am J Respir Cell Mol Biol $12:$ 196 204, 1995.

32) Shimizu T, Takahashi Y, Kawaguchi S, et al : Hypertrophic and metaplastic changes of goblet cells in rat nasal epithelium induced by endotoxin. Am J Respir Crit Care Med $153:$ 1412 1418, 1996.

33) Li JD, Feng W, Gallup M, et al : Activation of NF- $\kappa$ B via a src-dependent Ras-MAPK-pp90rsk pathway is required for Pseudomonas aeruginosa-induced mucin overproduction in epithelial cells. Proc Natl Acad Sci USA 95 : 5718 5723, 1998.

34) Klinger JD, Tandler B, Liedtke CM, et al : Proteinases of Pseudomonas aeruginosa evoke mucin release by tracheal epithelium. J Clin Invest $74: 1669 \sim 1678,1984$.

35) Lee HS, Majima Y, Sakakura Y, et al : Quantitative cytology of nasal secretions under various conditions. Laryngoscope $103:$ 533〜 537, 1993.

36) 大山 勝: アラキドン酸カスケード代謝物. 上気道粘膜の 病態生化学. 51 57頁, 斯文堂, 鹿児島, 1984 .

37) Sakakura Y, Majima Y, Ukai K, et al : Nasal mucociliary clearance under various conditions. Acta Otolaryngol $96: 167 \sim 173,1983$.

38）間島雄一, 坂倉康夫 : 慢性副鼻腔炎に打ける後鼻漏の原因 とその治療. 日鼻誌 $37: 279 \sim 283,1998$.

39) Majima Y, Harada T, Shimizu T, et al : Effect of biochemical components on rheologic properties of nasal mucus in chronic sinusitis. Am J Respir Crit Care Med $160: 421 \sim 426,1999$.

40) Hirata $K:$ Dynamic viscoelasticity of nasal mucus from children with chronic sinusitis. Mie Med J $34: 205 \sim 219$, 1985.

41) Auphan N, DiDonato JA, Rosette C, et al : Immunosuppretion by glucocorticoids ; inhibition of NF- $\kappa \mathrm{B}$ activity through induction of $\mathrm{I} \kappa \mathrm{B}$ synthesis. Science $270: 286 \sim$ 290, 1995.

42) Lundgren JD, Hirata F, Marom Z, et al : Dexamethasone inhibits respiratory glycoconjugate secretion from feline airways in vitro by induction of lipocortin (lipomodulin) synthesis. Am Rev Respir Dis 137 : 353 357, 1988.

43) Rhee CS, Majima Y, Cho JS, et al : Effects of mucokinetic drugs on rheological properties of reconstituted human nasal mucus. Arch Otolaryngol Head Neck Surg 125 : $101 \sim 105,1999$.

44) Majima Y, Hirata K,Takeuchi K, et al : Effects of orally administered drugs on dynamic viscoelasticity of human nasal mucus. Am Rev Respir Dis $141: 79 \sim 83,1990$.

45) Braga PC, Piatti G, Grasselli G, et al : The influence of seaprose on erythromycin penetration into bronchial mucus in bronchopulumonary infections. Drugs Exp Clin Res 18 : 105 111, 1992.

$$
\left(\begin{array}{l}
\text { 別刷請求先 : 間島雄一 } \\
\text { †514-8507 津市江戸橋2-174 } \\
\text { 三重大学医学部耳鼻咽喉科学教室 }
\end{array}\right)
$$

